\title{
Why RMB should be more flexible
}

\author{
Article
}

Accepted Version

Kan, Y. Y. (2017) Why RMB should be more flexible. Journal of Financial Economic Policy, 9 (2). pp. 156-173. ISSN 17576385 doi: https://doi.org/10.1108/JFEP-08-2016-0058 Available at https://centaur.reading.ac.uk/71246/

It is advisable to refer to the publisher's version if you intend to cite from the work. See Guidance on citing.

To link to this article DOI: http://dx.doi.org/10.1108/JFEP-08-2016-0058

Publisher: Emerald Publishing Limited

All outputs in CentAUR are protected by Intellectual Property Rights law, including copyright law. Copyright and IPR is retained by the creators or other copyright holders. Terms and conditions for use of this material are defined in the End User Agreement.

\section{www.reading.ac.uk/centaur}

\section{CentAUR}

Central Archive at the University of Reading

Reading's research outputs online 


\title{
Why RMB should be more flexible
}

\begin{abstract}
This report examines recent developments relating to the Chinese government's policy actions and the key issues that determine the choice of exchange rate regime in China. An up-to-date "stock-take" of the economic indicators is conducted to determine what is suitable for China. The rationale for a two-way flexible exchange rate regime is reached from five major perspectives. First, a more flexible exchange rate regime can play a complementary role towards rebalancing the Chinese economy by raising the buying capacity of families, rebalancing growth towards domestic consumption, and reducing reliance on export. Second, China's price elasticity of the demand for exports was relatively low that the appreciation of the Chinese currency has almost no influence on optimizing China's trade balance. Third, capital inflows have slowed down while capital outflows have picked up. A more flexible twoway flow in RMB would be suitable under the current cash flow scenario in China. Fourth, a more market-based exchange rate with reduced intervention will facilitate further adjustment in reserves. Lastly, in the early stage of RMB internationalization, flexibility in the exchange rate is one of the factors that influences its growth prospect as a reserve currency.
\end{abstract}

\section{Introduction}

For the last 10 years, China is accused of undervaluing renminbi (RMB) and caused the persistent and massive trade deficit in US. There was global pressure, known as "China bashing" to make RMB more flexible and let it appreciate against the dollar. ${ }^{1}$ In addition, the recent uncertainty and fluctuation of RMB raise a number of questions about the policy actions of the People's Bank of China (PBC) over time.

This report examines the recent developments and trends relating to the Chinese government's policy actions and the key issues that determine the choice of exchange rate regime in China. An up-to-date "stock-take" of the economic indicators is conducted to determine what is suitable for China in light of the rapidly evolving nature of the world economy and trading environment. This paper discusses the role of economic development, trade competitiveness, capital flow, foreign exchange reserve, and RMB internationalization in the determination of the RMB exchange rate regime. It presents the rationale behind a more flexible two-way exchange rate, by assessing empirical data and theoretical explanation that support such a move.

With China now the globe's largest economy based on purchasing power parity (International Monetary Fund, 2015), an analysis of the RMB exchange rate is vital because of the globalized nature of foreign exchange markets and their interconnectedness. Exchange rates can affect the price of imports and exports, as well as the value of international investment. The undervaluation or overvaluation of RMB has been a recurrent issue and has an impact on global and domestic economies in terms of risk, profits, and investment. The challenges faced by China change over time, suggesting a need to adapt to changing circumstances. Revisiting the current factors that impact on the exchange rate policy is, therefore, a useful exercise for policy decision-making.

The paper is organized as follows. Section 2 reviews major literature and empirical studies to put the many diverse views on the pegged and unpegged positions of RMB into perspective. Section 3 describes the research methodology and data set employed. Section 4 provides an 
overview of the major historical developments and trends in China's exchange rate, in order to analyze the Chinese government's exchange rate policy stance. Following which, factually supported rationales are presented to explain why the RMB exchange rate should be more flexible. Finally, Section 5 concludes the findings.

\section{Literature review}

China's exchange rate policy has been a subject of intensive investigation and debate over the last two decades. The debate in early 2000 focused on whether RMB was undervalued. By 2005, much attention was being given to whether China should or should not unpeg its currency.

Roubini (2007) commented that China should allow its currency to appreciate significantly and move to a more flexible regime. His arguments were driven by large Chinese trade and current account surpluses, coupled with massive amounts of foreign direct investment and hot money flowing into China. A failure to allow a nominal appreciation would pose significant risks to China. These risks include protectionist trade policies against China by U.S. and Europe, asset bubbles from excessive liquidity and credit, excessive reliance on net exports and real investment at the expense of private consumption, capital losses from huge reserves, as well as inflation risk (Roubini, 2007).

In contrast, McKinnon (2005) argued that appreciation of RMB is not good for China for a few reasons. First, China exports would be seen to be more expensive in foreign exchange. This would lead to a sharp loss in mercantile competitiveness in export markets, followed by a general slowdown in its economic growth. Second, there would be a negative investment effect. A substantial appreciation would make the country look like a more expensive place to invest and investment would decrease. Third, the position as an international creditor with net dollar assets could lead to negative wealth effect. If RMB appreciates, the huge dollar assets would lose substantial value in terms of the domestic currency. This negative wealth effect could further reduce domestic consumption as well as investment, and aggravate the growth slowdown in the China's economy (McKinnon, 2005).

Goldstein and Lardy (2009) argued that refusal to revalue the RMB would sustain its undervaluation. An undervalued RMB would cause distortion to domestic investment decisions and undermine the transition to a more consumption-driven growth. As a result, investment and human resources would be retained in the lowest value-added industries, thus hinder the growth and expansion of both service and specific industries that China seeks to develop. In addition, the perpetuation of RMB undervaluation by large-scale intervention in the foreign exchange market would need to be accompanied by continued sterilization, which would result in increase in the money supply and inflationary pressure (Goldstein \& Lardy, 2009).

Moosa and Burns (2012) discussed these accusations and reached the conclusion that there was nothing immoral or illegal about Chinese policies. It was suggested that China is pursuing policies that are suitable to its stage of development. It is appropriate for countries to adopt economic policies deemed suitable for their domestic economic conditions, which naturally change over time. This discussion led to the conclusion that China has the right to choose its own exchange rate regime.

Moosa and Ma (2013) further argued that the U.S. trade deficit is an American problem resulted from excessive spending, high indebtedness, inadequate saving rate, and the abandonment of 
the manufacturing industry. The alleged under-valuation of the RMB was not the root cause of the U.S. trade deficit with China. This discussion led to the conclusion that China has the right to choose its own exchange rate regime.

Chao and Tung (2013) examined Chinese official documents, records of bilateral meetings, and other testimony and concluded that China's exchange rate policy was influenced by U.S. political pressure, and that this pressure led to reform of the RMB exchange rate regime and the widening of the floating band of the RMB exchange rate.

There are neutral view on the exchange rate policy of China. Frankel (1999) argued that no single currency regime is best for all countries at all times. Countries are increasingly pushed to choose between the polar cases of free floating and rigid pegging. Countries have to trade off the advantages of more exchange rate stability against the advantages of more flexibility (Frankel, 1999).

There are empirical studies that focus on the impact of exchange rate on trade but the findings are inclusive. Exchange rate regimes are not really connected with global current account imbalances. According to an empirical study by Corden (2009), global current account imbalances have been associated with all kinds of exchange rate regimes (Corden, 2009). Stiglitz (2005) argued that revaluation and eliminating China's trade surplus would have little effect on the more important problem of global trade imbalances and particularly on the US trade deficit. Cheung et al. (2007), using dynamic OLS methods, found that an appreciation of the RMB increases US exports to China but does not affect China's exports to the US. In the study by Zhang and Sato (2012), the results from VAR estimations indicated that the dynamic effect of exchange rate on China's trade balance was still very limited. China's trade balance was found to be affected largely by the world demand shock and trade balance shock (Zhang $\&$ Sato, 2012). However, Yu (2012) had a different results. Using a variety of econometric methods to cover a sample period of 2002-2008, the appreciation of the RMB against the U.S. dollar was found to significantly reduced imports to the United States from China (Yu, 2012). Overall, the role of a flexible exchange rate regime in facilitating current account adjustment may be vastly exaggerated.

In view of the opposing views in the literature, this paper re-examines both points of views based on recent developments in China. The author is of the opinion that exchange rate regimes ought to be dependent on a country's individual circumstances. This research intends to provide an up-to-date "stock-take" of the economic indicators on this issue, in light of the rapidly evolving nature of the world economy and trading environment. 


\section{Research methodology}

This research uses an inductive approach to gain a fine-grained understanding of the complex, multifaceted aspects of China's exchange rate policy. A combination of statistical analysis, including basic descriptive statistics, trend analysis, and a correlation study are used to explore the association between various indicators and their implications. The report also draws on analysis of a broad range of data sources and the work of numerous researchers and research institutions.

The data are collected from official sources such as the World Bank, IMF, and National Bureau of Statistics of China. Key stylized facts are presented, using simple descriptive statistics to explain variables such as consumptions, investment, savings, and their implications on RMB exchange rates. Trend analysis is used to analyse the general direction of various macroeconomic indicators over time. Rational analysis of development patterns provides a far more reliable basis for speculation and prediction than reliance on mere intuition. Combining several trends, and noting trend reversal can generate a rich picture of how the indicator might develop.

The findings and conclusion are derived based on the latest empirical information, statistical evidence, and economic theory. This inquiry does not build on a theory, and aims to neither verify a theory, nor test hypotheses. Rather, it aims to demonstrate, assess, and explain significant roles that various economic factors play in shaping the future exchange rate regime of China.

\section{Data analysis}

The data analysis begins with a review and analysis of the recent (2011-2015) RMB trend, in order to understand the last developments surrounding China's exchange rate regime. In addition, this section also examines the Chinese government's policy stance and official announcements, as there is a perceived discrepancy between the official (de jure) exchange rate policy and the observed de facto exchange rate policy.

Figure 1. Exchange rate of RMB per USD

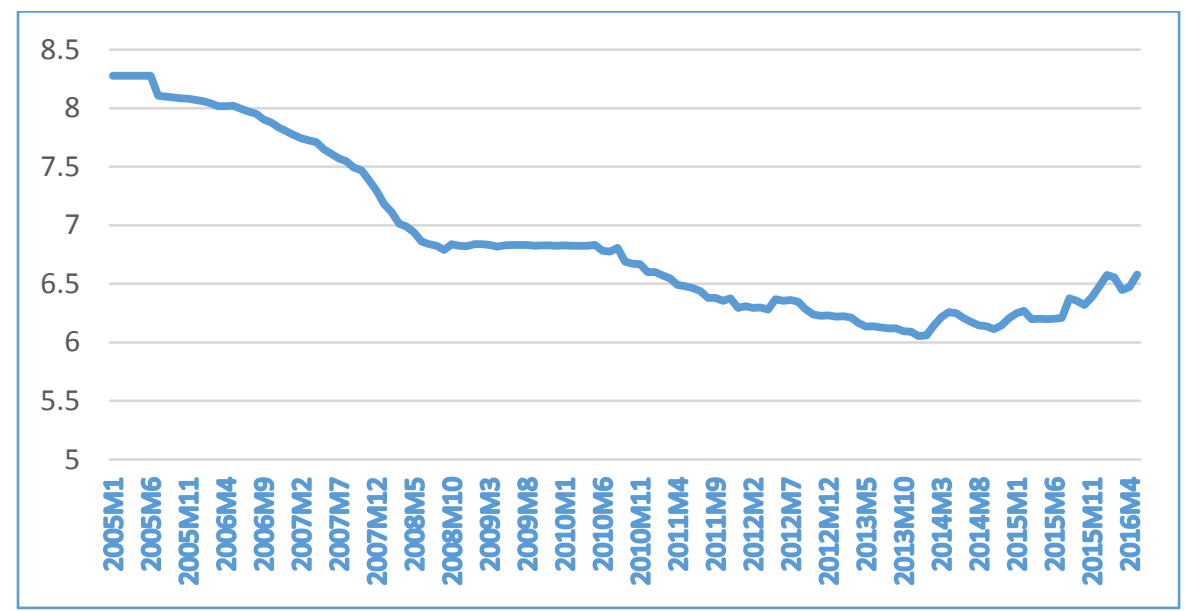


After the global financial crisis, RMB continued its appreciation, registering an increase of $4.7 \%$ in $2011,1.0 \%$ in 2012 and $2.9 \%$ in 2013. During this period, the PBC intervened in the foreign exchange market. The average daily volatility of RMB was $0.0015 \%$ for the period $2011-2015$ (Figure 1).

The trend reversed from appreciation to deprecation in February 2014. At a two-day meeting ending February 18, 2014, the central bank of China decided to weaken the RMB (The Economist, 2014). On February 19, 2016, RMB fell 14.98\% to RMB 6.0762/USD. On February 26, 2014, China's foreign exchange regulator said that China's ongoing exchange rate reforms meant that two-way fluctuations would become the norm (The Economist, 2014). The move in February 2014 was called a surprise mini-devaluation (McKinnon, 2014). In midMarch 2014, the PBC further announced that the daily movement in the yuan/dollar rate would be increased from plus or minus $1 \%$. The RMB registered a depreciation of $2.4 \%$ in 2014 in the backdrop of a surge in capital outflows, two-way trading, and higher volatility.

On August 10, 2015, China's central bank announced a new "exchange rate mechanism". RMB could move up or down by not more than $2 \%$ on a daily basis, based on two factors: the previous day's closing rate and the value of a basket of currencies, not just the dollar. If implemented in full, the new system would give market forces a bigger role (The Economist, 2016). The PBC said it would make RMB's value more market based, an important step in liberalizing China's economy (Wei, 2016). Until then, the value had been entirely determined by the central bank itself. The PBC paired the policy shift with a devaluation of almost $2 \%$. The announcement came with few details and scant explanation, and triggered a fall of 1.8\%, RMB's largest oneday drop since 1994 (Figure 2).

Figure 2. Daily volatility of $R M B$

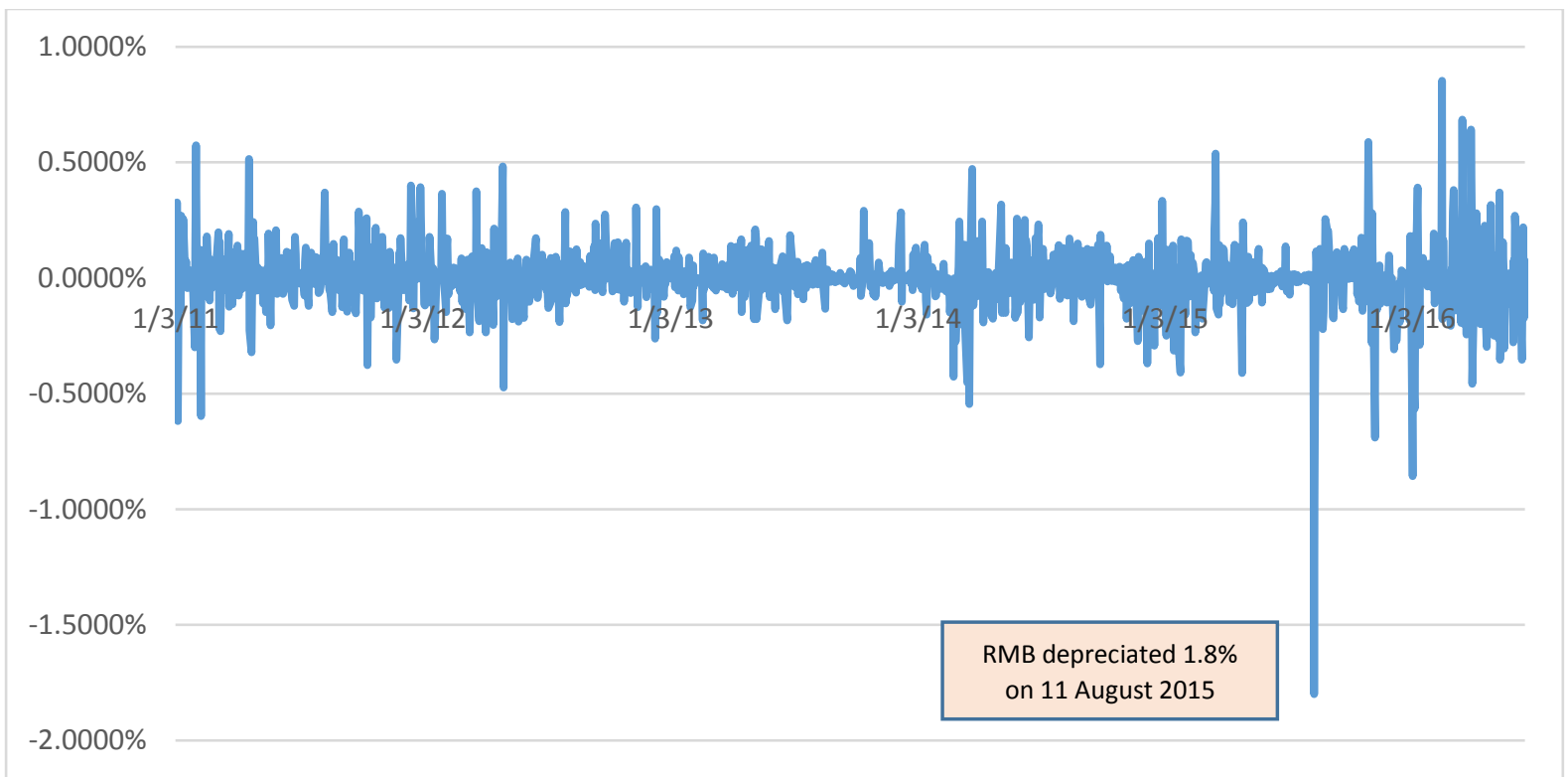

(Source: Federal Reserve, Bilateral Exchange Rates and author's calculation)

On December 12, 2015, China's central bank announced its intention to change the way it managed the RMB's value by potentially easing its loose peg to the U.S. dollar and instead 
letting it track the currencies of its broader trading partners. In an editorial posted on its website, the PBC said the RMB's exchange rate would be better measured against a basket of currencies rather than the dollar alone. For the first time, the foreign-exchange trading system run by the central bank published the composition of the currency basket, which comprised the dollar, euro, yen and 10 other currencies. The central bank didn't offer additional details on a timetable for when it actually would change the way it managed the yuan (Wei, 2015). Overall, RMB registered the highest depreciation record of $4.2 \%$ in 2015 (Figure 3).

Figure 3. Annual percentage change in RMB (2011-2015)

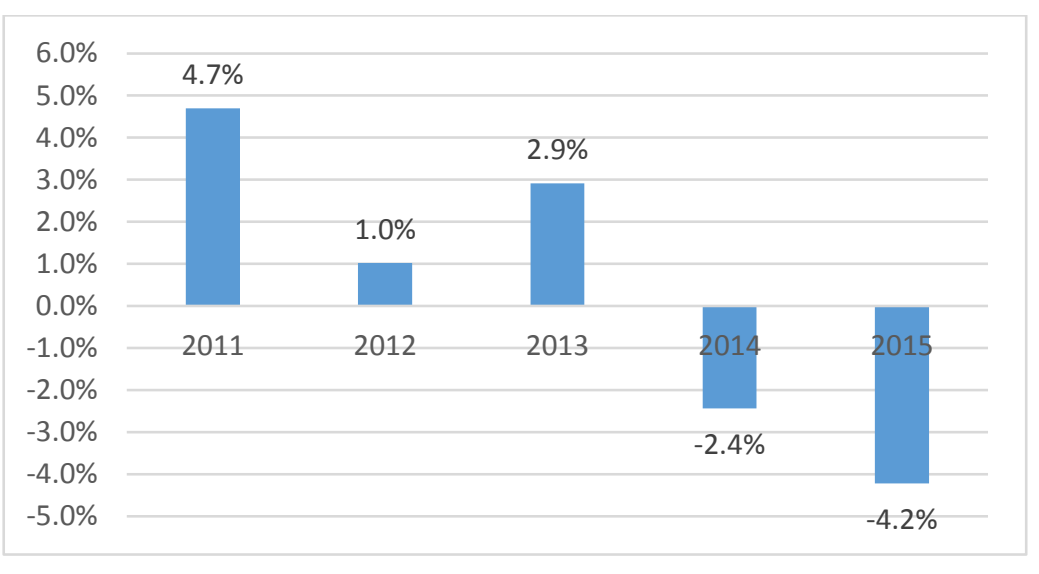

At the start of 2016, it was reported that cash poured out of China as the Federal Reserve raised interest rates and hedge funds lined up to bet against the RMB (The Economist, 2016). On January 4, 2016, it was reported that "the China's central bank ditched the market-based mechanism returned to the old way of adjusting the RMB's daily value higher or lower based on whatever suits China best" (Wei, 2016). The RMB gained 2\% against the dollar from midJanuary 2016 to mid-March. Again, it was reported that "some of China's most prominent economists and bankers bluntly asked the PBC to stop fighting the financial markets and let the value of the nation's currency fall in March 2016" (Wei, 2016). Since the end of April 2016, RMB depreciated three weeks in a row. Even though the Chinese government did not announced any change or reversal in policy, RMB was volatile over the first half of 2016. It is uncertain if the fluctuation of RMB was caused by market forces or speculation and how far the $\mathrm{PBC}$ was involved in intervention to prevent currency appreciation or to prevent deprecation in the face of capital outflow.

RMB's exchange rate flexibility has increased progressively with an enlarged trading band over time. The RMB trading band vis-à-vis the US dollar was initially set at a tightly controlled range of $\pm 0.3 \%$, which was later widened to $\pm 0.5 \%$ in May $2007, \pm 1 \%$ in April 2012, and then to $\pm 2 \%$ in March 2014 (Kawai \& Liu, 2015). Although the current exchange rate regime in China is claimed to be a managed-floating one, the daily fluctuations are still very limited, as evidenced by the small increase in daily standard deviation from $0.13 \%$ in 2011 to $0.17 \%$ in 2015 (Figure 4). 
Figure 4. Standard deviation of daily change in RMB (2011-2015)

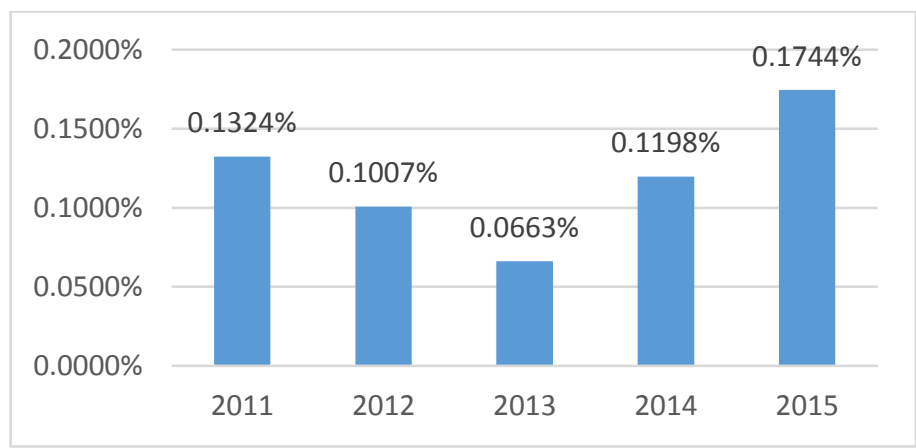

There are some important conclusions that emerge from the analysis. First, the exchange rate regime choice is governed by the PBC. The Chinese government pursued policies that are suitable to the country's circumstances, stage of development, and economic conditions while adjustments are made over time. Instead, under the IMF system, countries have a choice of adopting their preferred exchange rate regime. Article IV of the revised IMF articles allows countries to "tie their currencies to any external anchor with the sole exception of gold"meaning fixed exchange rates. Any country is free to choose to peg its currency if it wishes. Instead, the central bank of China has retained considerable power.

Second, in setting the daily rate it can also choose whether to focus on the dollar or on the basket, as suits its purposes. The PBC may not stick to its stated policy. Although the PBC said the central bank guides the daily direction of the currency by alternating between setting RMB's value against the dollar and a basket of currencies, it did not unveil the exact weight of each component currencies in the RMB basket. Frankel and Wei (2007) evaluated the exchange rate regime of China and found that within 2005, the de facto regime remained a pegged to a basket that put virtually all weight on the dollar. Subsequently some weight was shifted to a few non-dollar currencies. The peg was still fairly strong in 2006 (Frankel \& Wei, 2007). A subsequent study by Cui (2014) examined how the RMB pegs to its currency basket and estimated the weight of each of component currencies over the period from January 2007 to March 2013. The results illustrated that the RMB did not perfectly peg to the RMB basket as the PBC announced during the period from January 2007 to March 2013. The US dollar's weight was found to have declined steadily since 2011, although it was still the most important reference currency to peg for the RMB. Other currencies, such as the Singapore dollar, received increasing weight in RMB basket. It implied that RMB exchange rate regime was in the transitional period from single currency peg to currency basket peg (Cui, 2014). From this empirical study, the dollar played a major role in influencing the exchange rate of RMB.

Third, a key words analysis from the announcements revealed that China's government is loosening its peg and moving towards a managed floating system against a basket of currencies over time. In early 2016, when the dollar was weak, the central bank of China has tethered the RMB to it, thereby allowing depreciation against the basket of currencies. When the dollar strengthened, PBC let the RMB creep down against it, thereby limiting its appreciation against the basket (The Economist, 2016). The uneven approach to making the RMB exchange rate more flexible revealed the dilemmas between the Chinese government's desire to free up RMB and its tendency to override the market when they do not produce the results it wants. 
It is also noteworthy to highlight that the phase of severe undervaluation of RMB is now well in the past as history. The study by Cline (Cline, 2016) estimated that the undervaluation of the RMB had been less than 5\% in 2012 and disappeared by late 2014. The IMF (2015) also reported that substantial real effective appreciation has brought RMB to a level that is no longer undervalued. Given the sizable 35\% real appreciation of RMB since 2005, the subdued current account surplus is also an indication of that RMB is no longer undervalued. On the other hand, RMB is not overvalued, so there is no technical reason to expect it to fall sharply.

A right choice of exchange rate regime is important to prevent distortion in trade and domestic investment decisions. Section 4 provides an overview and discusses the latest economic issues surrounding China's currency policy. Factually supported rationale are presented to explain why the two-way flexibility of RMB should be increased.

\subsection{Economic development}

Since 2015, economic growth in China has been moderating. IMF reports described China as moving to a "new normal" characterized by slower yet safer and more sustainable growth (IMF, 2015). Gross domestic product expanded 6.9\% in 2015 (Figure 5), indicating the growth model led by investment and exports may not be sustainable. China's economy needs to meet the challenge of unwinding accumulated imbalances while preventing growth from falling too sharply.

Figure 5 China's gross domestic product growth (annual \%)

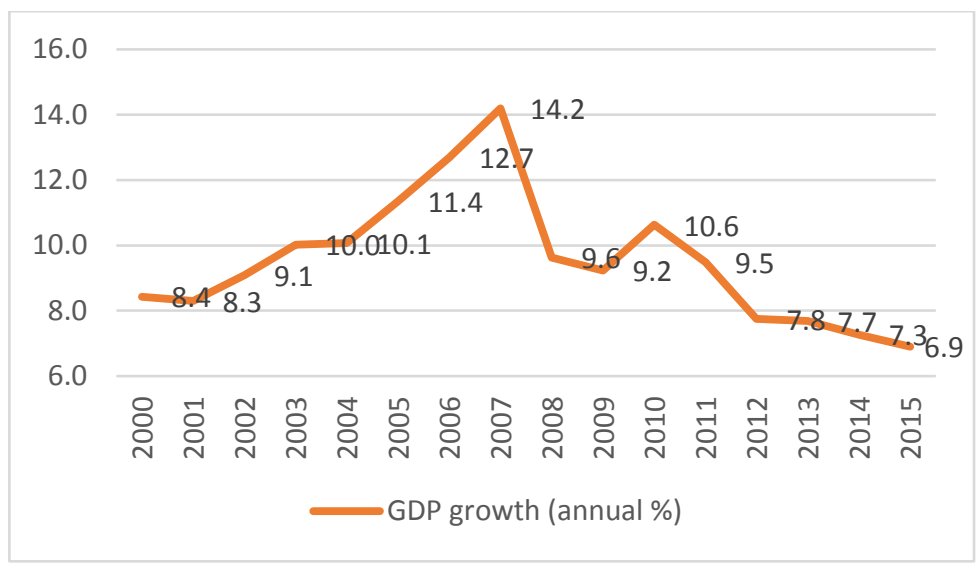

(Source: World Bank)

China's growth pattern was heavily reliant on investment. After Year 2006, household consumption expenditure in China fell below 40\% of GDP and continued to be sluggish. On the other hand, investment rose from 40\% of GDP in 2006 to 46\% in 2014 (Figure 6). Based on the most recent data, the long-term trend reversed with consumption increased from a trough of $36 \%$ in 2010 and investment declined from a peak of $47 \%$ in 2011 . There is a need to move from an investment-led economy to a consumption-led economy for a more balanced and sustainable GDP growth. 
Figure 6. Household consumption and investment as percentage of GDP

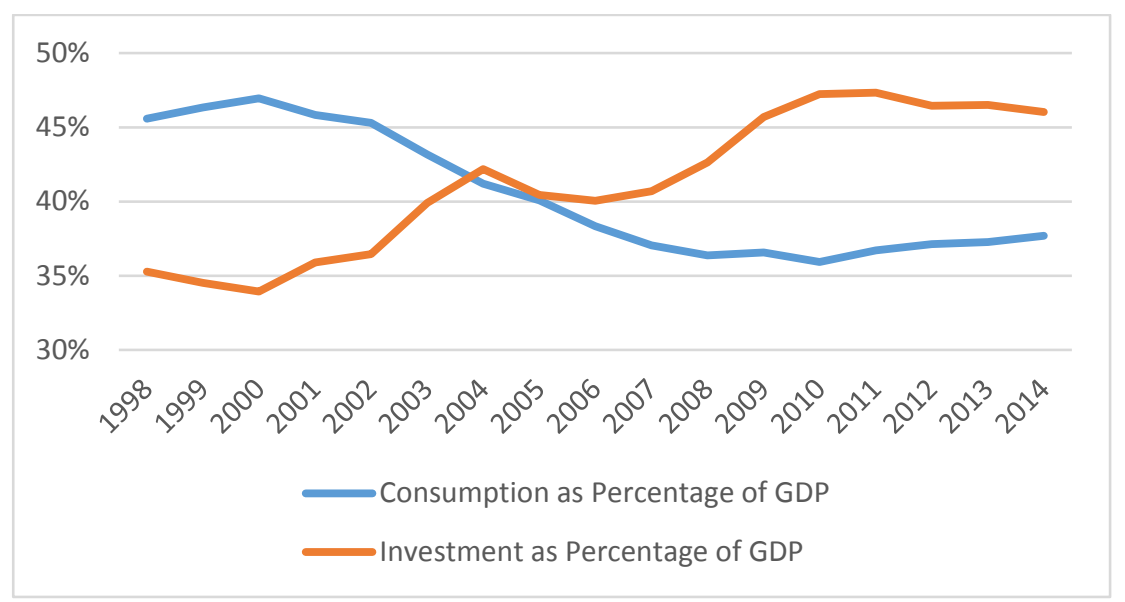

(Source: IMF and author's calculation)

China has high savings rates, which registered a record high of 53\% of GDP in 2008 (Figure 7). The saving rates continued to hold up high at 50\% of GDP in 2015. As savings have risen faster than investment, there is a need to reform to increase consumption, reduce excess savings, achieve sustained external balance, and move to a more market-based financial system.

Figure 7. Gross national savings as a percentage of GDP

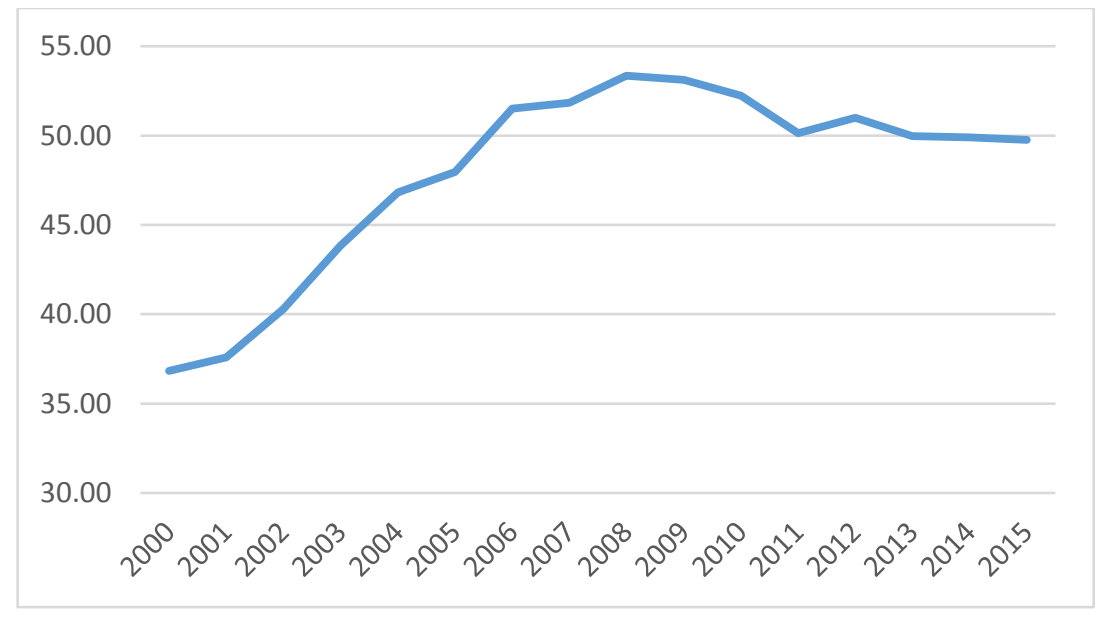

(Source: IMF)

In the past, the Chinese government was reluctant to appreciate RMB despite "China bashing" due to the negative investment effect. An appreciation makes the country a more expensive place for foreign direct investment. As the focus is now on stimulating consumption, more flexibility can be given to the RMB exchange rate. Strengthening of consumption over investment and export will reduce China's current account surplus. Exchange rate policy can be used as a tool.

A more flexible exchange rate regime can play a complementary role towards rebalancing the Chinese economy by raising the buying capacity of families, rebalancing growth towards 
domestic consumption and reducing reliance on export. It would help to shift production from exports to goods and services for home use. This can be attained in the case of RMB appreciation.

In addition, a more flexible, market-determined exchange rate is needed to maintain an independent monetary policy. The de facto exchange rate system of China has limited the independence of China's monetary policy and contributed to pronounced macroeconomic fluctuations. Without exchange rate flexibility, China will have less room to use appropriate monetary policy to target its specific cyclical and structural problems. A more flexible exchange rate policy would allow greater flexibility in setting domestic interest rates and to mitigate macroeconomic cycles such as raising lending rates to moderate investment booms or lowering interest rates to stimulate growth.

A cautious note worth mentioning is an over-devaluation of RMB will squeeze the purchasing power of Chinese consumers and thus slow, the rebalancing of its economy from investment to consumption. Moreover, a shift to the service sector requires, and is facilitated by, a real appreciation of the exchange rate and structural reforms to raise productivity in the nontradable sector.

\subsection{Trade competitiveness}

For years, the Chinese government has been criticized for intervening in currency markets to limit or halt the appreciation of RMB against the US dollar. A weak currency makes exports cheaper to foreigners, which can lead to higher exports and job creation in the export sector. This has caused rapid growth in the current account surplus in China, reaching the peak of $10 \%$ for China in 2007.

The current account surplus narrowed to $4 \%$ in 2010 , and fell further to $2 \%$ in 2014 . The external position was close to equilibrium. The data reveals a sharp drop in China's current account surplus after the global financial crisis (Figure 8). According to the IMF, the decline reflected strong investment growth, real effective exchange rate appreciation, weakness in major advanced economics, and a trend in widening of the services deficit, mainly due to strong outbound tourism and education spending (IMF, 2015).

Figure 8. China's current account balance

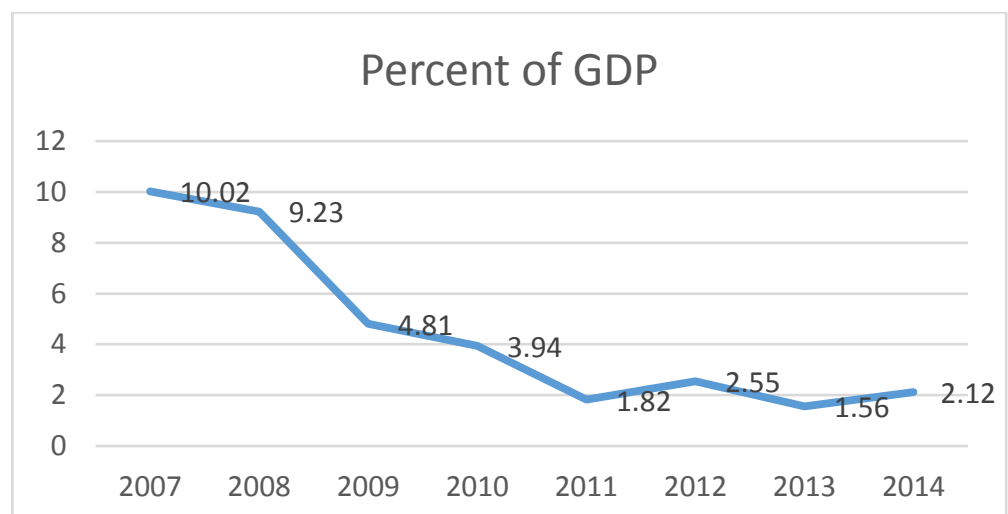

(Source: IMF) 
The correlation between the RMB exchange rate and current account balance in China is examined next. The selection of sample periods is based on the major period of change in China's exchange rate regime as discussion in Section 4 of this paper. Using USD/RMB (the price of one unit of RMB in dollars) in the analysis, the impact of RMB appreciation/depreciation on the current account balance is evaluated. After the flotation in July 2005, correlation was 0.82, indicating that an appreciation in RMB has a strong positive relation with current account surplus in China. Although China bashers suggest that as RMB appreciates, the trade deficit of US should shrink, this kind of effect is not evidenced in the data (Table 1). Instead, when RMB appreciated by $21 \%$ from 2005 to 2008, China's trade surplus did not reduce but increased by $300 \%$ over the same period. The empirical results from 2008 to 2015 were not statistically significant.

Table 1. Correlation between China's RMB exchange rate and current account balance

\begin{tabular}{|c|cccc|}
\hline $\begin{array}{c}\text { From } \\
\text { To }\end{array}$ & 2005Q1 & 2008Q3 & 2010Q2 & 2012Q1 \\
\hline \multirow{2}{*}{ Correlation } & 0.82 & 0.49 & -0.25 & -0.31 \\
& & & & \\
T statistics & 4.9603 & 1.2730 & -0.5670 & -1.2186 \\
\hline
\end{tabular}

Based on these findings, it can be concluded that appreciation in RMB is not sufficient to reduce its current account surplus. China's price elasticity of current account balance was relatively low and the fluctuation of RMB had almost no influence in optimizing China's trade balances. ${ }^{2}$ As such the RMB exchange rate can be relaxed to cater to the objective of economic rebalancing and capital flow management.

\subsection{Capital flow and hot money}

Over the past 10 years, international capital inflows to China increased because of improved macroeconomic fundamentals, remarkable economic growth, and greater investment opportunities. A surge in foreign capital inflow was accompanied by the "twin surpluses" in both current and capital accounts. Moreover, low interest rates in mature markets coupled with strong expectations of RMB appreciation boosted sizeable of hot money, which was short term and speculative in nature.

In the first quarter of 2013, it was estimated that $\$ 77.9$ billion of hot money flowed inwards. Much of this qualified as a carry trade, i.e., speculators borrowed cheaply in dollars, and then lent in RMB, hoping to benefit from higher Chinese interest rates and RMB's appreciation. ${ }^{3}$ The inflow of hot money could have put upward pressure on the RMB. However, as observed from the change in foreign exchange reserve, the PBC could have intervened to push down the $\mathrm{RMB} / \mathrm{USD}$ exchange rate in the second half of 2014 to deter speculators who had been betting on one-way appreciation of RMB. Hot money rises and falls quickly, and it is difficult to predict 
and monitor the amount flowing in and out of the country. In 2015, hot money flows had abated but its movement is full of uncertainty (Figure 9).

Figure 9. Hot money in China

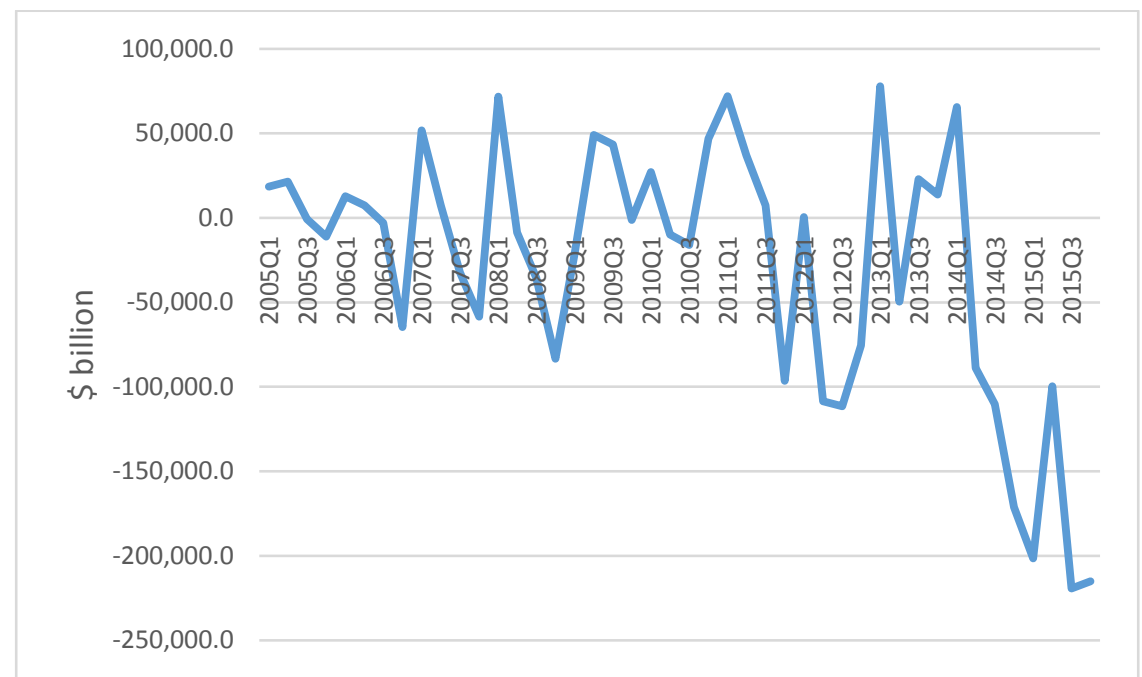

(Source: The People's Bank of China and author's estimate) ${ }^{4}$

A major factor for a massive inflow of hot money was a low interest rate environment in matured countries. From 2008 through late 2015, the Federal Reserve kept its policy rate, the federal funds rate at $0.25 \%$, which is essentially its lower bound near zero as a response to the financial crisis and the ensuing recession in 2008. The low rate remained until December 2015, when it was raised to $0.75 \%$ (Figure 10). A comparison of discount rates between the US and China shows that the reversal in the relative interest rates of the two countries has created an incentive for investors to move their deposits from the US to China in order to earn a higher rate of return. For example, with short-term interest rates in the US at $0.75 \%$ and China at $3.25 \%$ with a 3\% expected RMB appreciation, this translates into an effective interest rate differential of 5.5\%. This is an enticing spread for currency speculators who borrow in dollars and circumvent China's capital controls to buy RMB assets. The combined effects of the interest rate differences and the expected appreciation of RMB provide a strong incentive for hot money flows into China.

Figure 10. Comparison of discount rates in US and China

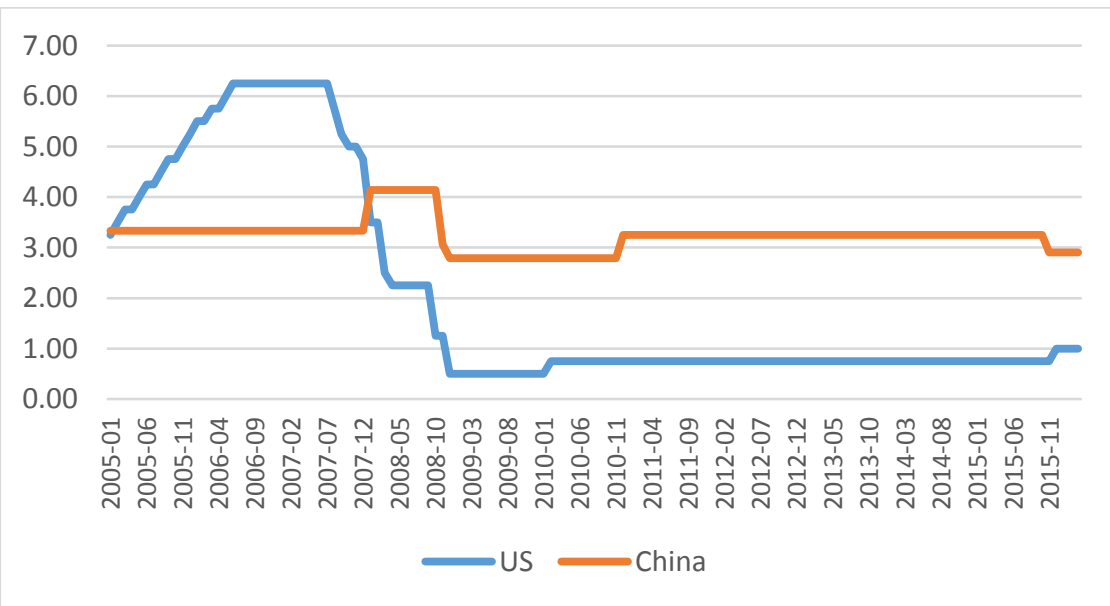

(Source: Federal Reserve) 
The large flow of hot money is causing a sharp rise in China's money supply, resulting in inflation. The lack of flexibility in the exchange rate effectively limits the ability of PBC to use monetary policy to control inflation. If the government raised interest rates, hot money would flow to China from abroad, forcing the government to buy up the foreign currency to maintain the targeted peg.

Another concern about hot money is the possible creation of a bubble in China's stock and real estate markets. There was upward pressure on property prices but the trend has eased in 2015 . China was trying to rein in speculation in property and equities without damaging industry. The real estate investment has slowed and adjusted in an orderly manner. Due to a build-up of inventory, the real estate market has moderated since late 2014 (Figure 11).

Figure 11. Real estate prices in China

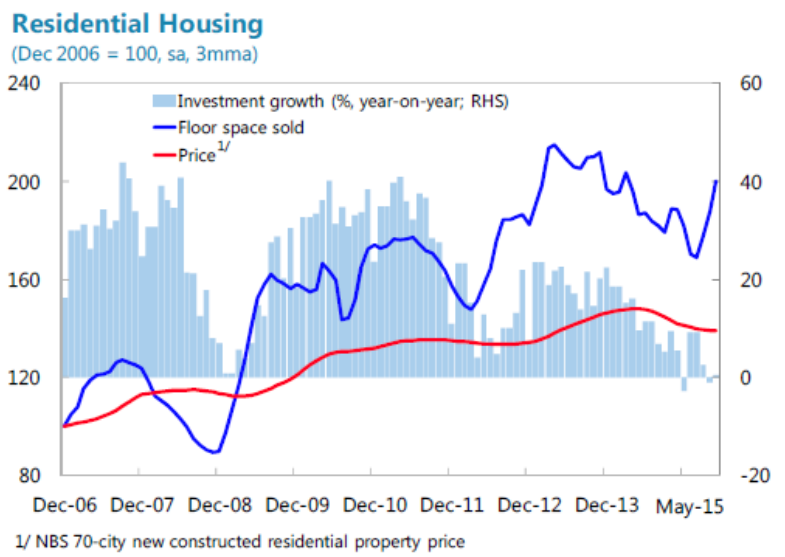

(Source: IMF)

Even though massive hot money is a concern, RMB has begun to face depreciation pressures since 2014 due to a surge in capital outflows. Capital outflows were driven by an expectation of RMB depreciation and the weakening of China's economic fundamentals (Yu, 2016). An estimated $\$ 1$ trillion left China in 2015 when the RMB devalued. ${ }^{5}$ The PBC actually intervened to mitigate the deprecation of RMB, as evidenced in the fall of the foreign exchange reserve to \$3.3 trillion in December 2014 and \$3.3 trillion in December 2015.

Onshore foreign exchange hedging activity was believed to have risen sharply in tandem with the depreciation of RMB since 2014. According to Lo (2015), the Bank for International Settlements estimated that the US dollar liability of onshore Chinese companies totalled US\$1.1 trillion. Lo (2015) estimated that if hedging amounted to 1\% of this liability, it would equal US\$11 billion, or more than $36 \%$ of daily onshore U.S. dollar spot and forward trading volume (about US\$30 billion). Although there was no official data for the amount of onshore hedging activity, this evidence shows the possibility of significant RMB depreciation if market players increase onshore foreign exchange hedging activity. Another consideration is Chinese citizens can move a maximum of $\$ 50,000$ abroad each year (The Economist, 2016). If $10 \%$ of the population uses this quota, China's reserves would be affected. These activities, if concentrated, could weaken the RMB significantly. 
Overall, capital inflows have slowed down while capital outflows have picked up. China needs to find a way out of this dilemma. A more flexible two-way flow in RMB would be suitable under the current capital flow scenario in China. An increase in the value of the RMB could control inflationary pressures caused by hot money and prevent Chinese citizens from taking money out of the country. On the other hand, depreciation of RMB could undermine the speculators and eliminate the driving incentives. Allowing more exchange rate flexibility can foster a sense of two-way risk to encourage market participants to take both long and short positions.

\subsection{Huge reserve}

To protect the export sector by undervaluing the RMB exchange rate, the PBC buys dollars received from export at the pegged rate and sells newly created RMB. Such intervention withdraws the surplus dollars from the foreign exchange market and neutralizes their oversupply effects on the exchange rate of RMB. The dollars purchased are then invested in foreign assets, mostly US government bonds. However, this intervention increases the supply of RMB and may lead to domestic inflation. To absorb the expanded supply of RMB, the Chinese government conducts sterilization by selling government bills and bonds. The Chinese government also relies on administrative controls (credit quotas) and reserve requirements.

China had $\$ 845$ billion foreign exchange reserves in January 2006, which increased by $264 \%$ to $\$ 2.85$ trillion in December 2010. The foreign exchange reserve in China peaked at nearly $\$ 4$ trillion in June 2014. The rapid accumulation of foreign exchange reserves is an indication of external imbalances and sizeable (one-sided) exchange rate interventions to prevent the appreciation of the RMB (Figure 12).

Subsequent to a peak of US\$4 trillion record high reserve in June 2014, the trend reversed. The foreign exchange reserves decreased by $2 \%$ to US $\$ 3.8$ trillion in September 2014. By December 2015, the foreign exchange reserves decreased further by $13 \%$ annually to $\$ 3.33$ trillion (Figure 12). The Chinese government could have sold foreign currency assets to support RMB from depreciation during this period. The US Treasury Department estimated that Beijing sold more than $\$ 480$ billion in foreign-currency assets from August 2015 through March 2016 to support RMB (Wei, 2016). The reserve dropped further to \$3.22 trillion in April 2016. 
Figure 12. China's foreign exchange reserves

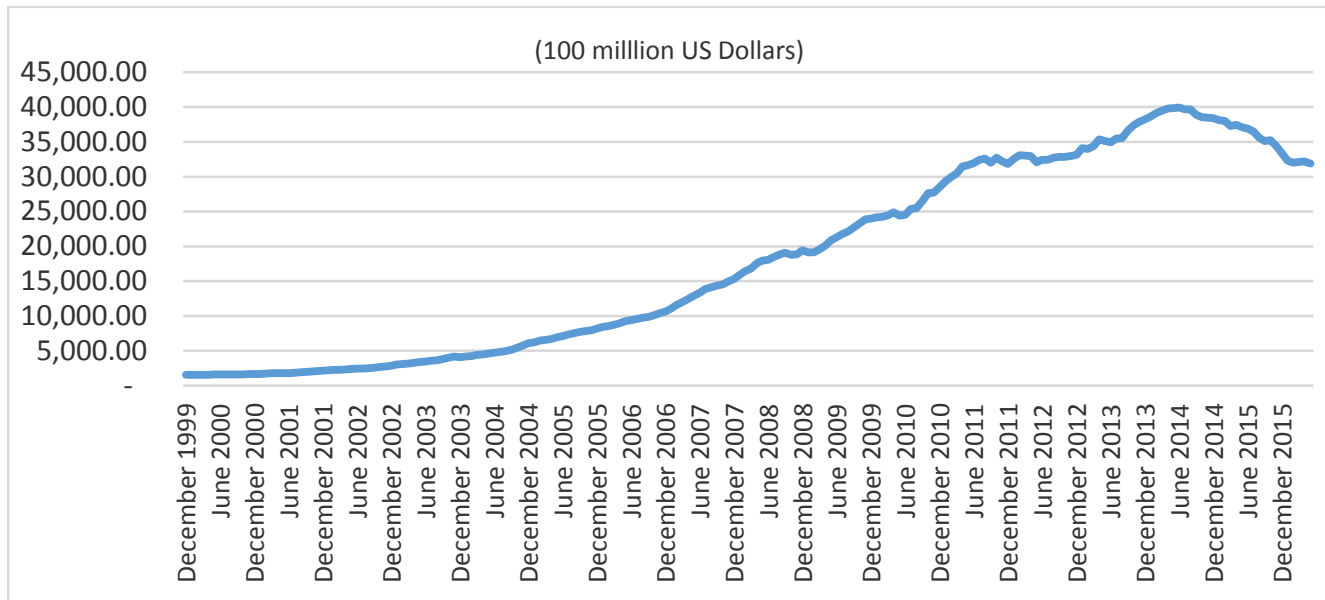

(Source: The People's Bank of China)

Although foreign exchange reserves are useful shield against currencies crises, there are detrimental effects and risks from holding huge foreign exchange reserves.

First, being an international creditor with net dollar assets, a negative wealth effect could arise when RMB appreciates. If RMB appreciates, the dollar assets held by China will lose value in terms of the domestic currency. Such a negative wealth effect could further reduce domestic consumption and investment, leading to a slowdown in the domestic economy.

Second, China's foreign exchange reserves are held in low return US Treasury bills, bonds and other dollar securities. China is paying a higher return to foreign investors on their inward investment than it is earning, which means that the arrangement is a losing deal for the country in the aggregate (Frankel, 2004). This creates an exorbitant privilege to US residents, who enjoy higher return on foreign assets and pay lower real return on US liabilities to foreigners. China as, a reserve accumulator, experiences a negative different between real returns on foreign assets and returns on foreign liabilities.

Third, China's large stock of foreign exchange reserves tied up in US Treasury securities helps fund US government spending while depriving Chinese people of private sector investments that could increase real income and consumption. It is inappropriate that a developing country with a low per capital income as China, a capital-poor country, to be exporting capital. ${ }^{6}$

Fourth, sterilization can become increasingly difficult over time, especially if traditional barriers to capital flows have been gradually eroded. Sterilized intervention will prevent the interest rate differential from narrowing, and may induce further inflows.

Lastly, sterilization to maintain a fixed exchange rate results in fiscal costs, losses from intervention and increase in public debt. This is because PBC has to pay higher interest rates to domestic banks for voluntarily absorbing the sterilization bonds. On the other hand, PBC receives relatively lower interest rates on its reserves, which consist moslty of US Treasury securities. If the government sells bonds to the domestic banks without paying market interest rates, a form of financial repression happens. This would weaken the balance sheets of local banks and raises the probability of a banking crisis. 
In light of the problems discussed above, it is important to relax the peg and let the market determines the exchange rate. The government would not have to purchase US assets to maintain the peg, nor hold excessive amounts of dollar assets. The level of reserves required to maintain a flexible rate is lower than that required to maintain a fixed one. A more marketbased exchange rate with reduced intervention will facilitate further adjustment in reserves.

\subsection{RMB internationalization}

Since 2009, China has been promoting the international use of RMB. These efforts include permitting the use of RMB for settlement of trade transactions, permitting selected banks to offer offshore RMB deposit accounts and creating a payment system for easier settlement of cross-border RMB transactions. To increase international presence, China also allowed the issuance of RMB-denominated bonds in Hong Kong and set up offshore RMB clearing centers in Frankfurt, Paris, and London (Prasad, 2016). Up to September 2015, there were 19 RMB clearing centers worldwide and over 1,000 banks worldwide accept RMB to settle trade deals (Rapoza, 2016).

Internationalization carries long-term benefits such as heightened prestige and influence, improved trade efficiency, and seigniorage coming from having a country's currency circulating abroad and held as a reserve (Huang \& Lynch, 2013). It also carries costs, such as loss of monetary control and exchange rate volatility.

On December 1, 2015, IMF announced that RMB was to be included in the basket of currencies which make up the IMF's Special Drawing Rights (SDR). This was the first time in over 15 years that the list of currencies comprising the SDR had been altered. China was the only emerging market economy in the basket at that point of time. The revised SDR basket will be based on the following weights: $41.73 \%$ for the U.S. dollar; $30.93 \%$ for the euro; $10.92 \%$ for the Chinese RMB; 8.33\% for the Japanese yen, and 8.09\% for the British pound (International Monetary Fund, 2015). The IMF further announced in November 2015 that RMB met the criterion of a freely usable currency and would therefore be included in the special drawing rights (SDR) basket with effect from October 1, 2016. This event marked a milestone in China's initiative to internationalize its currency and move towards financial liberalization to better integrate with the world economy.

Nevertheless, RMB internationalization faces its own challenge. In June 2016, RMB slipped to sixth place as the most utilized currency in the world for cross-border payments. RMB has a $1.72 \%$ share of international payments (China Economic Review, 2016). The Canadian dollar has overtaken the RMB with a $1.96 \%$ share of world payments.

China has the determination to make RMB a global currency, with a value determined more in line with other major currencies, and to step out of the dollar's shadow as the world's de facto currency. In the absence of an open capital account and free convertibility of the currency, it is unlikely that RMB will become a prominent currency. RMB internationalization is still at its early stages. Flexibility in the exchange rate is one of the key factors that influences RMB's prospect as a reserve currency. Reserve currencies trade freely and their external value is market determined. Furthermore, a two way exchange rate movement is essential to give market participants an incentive to develop hedging instruments and manage exchange rate risk. 


\section{Conclusion}

The exchange rate regimes ought to be dependent on a country's individual circumstances. A country's de jure exchange rate regime could be quite different from the de facto regime. The selection of an exchange rate regime is a continuous process. The current concern for China's economy is a slowdown in GDP growth and declining foreign reserves. The current focus of policy in China is more on dealing with domestic imbalances and promoting the currency's international use, but less on correcting external imbalances.

China's economic development in the past ten years (2005-2015) has been marked by both large domestic and external imbalances. A pegged exchange rate system, capital controls, interest rate control, and the lack of flexibility could lead to the accumulation of domestic macroeconomic and financial imbalances in the form of a huge trade surplus, foreign exchange reserve, and investment boom, as well as distortion in the price system.

Against this backdrop, the PBC should deepen and broaden the foreign exchange market to reflect changes in both domestic and external economic conditions and market forces. From the analysis, the recommendation of this paper is that it is now probably now time to allow RMB to have more flexibility toward two-way fluctuations by widening the band further in the next five years. It is no longer the optimal choice for China to maintain a dollar-peg policy. This need not mean a move to a pure floating regime before fully liberalizing its capital markets. It is optimal to gradually allow RMB to fluctuate based on market signals, to return to normal price discovery and not because of central directives. Intervention should be limited to avoiding disorderly market conditions or excessive volatility. Continuous intervention will deplete the reserve. While the current account is still in surplus and with ample foreign reserve, the timing is right to implement the change.

The rationale behind a two-way flexible exchange rate regime is reached from five major perspectives. First, a more flexible exchange rate regime can play a complementary role towards rebalancing the Chinese economy, by raising the buying capacity of families, rebalancing growth towards domestic consumption, and reducing reliance on export. It would help to shift production from exports to goods and services for home use. This can be attained in the case of RMB appreciation. Second, appreciation in RMB is not sufficient to reduce its current account surplus. China's price elasticity of demand for exports was relatively low so that the appreciation of the Chinese currency had almost no influence on optimizing China's trade balances. As such the RMB exchange rate can be relaxed to cater to the objective of economic rebalancing and capital flow management. Third, capital inflows have slowed down while capital outflows have picked up. A more flexible two-way flow in RMB would be suitable under the current cash flow scenario in China. An increase in the value of the RMB could control inflationary pressures caused by hot money and can prevent Chinese citizens from taking money out of the country. On the other hand, depreciation of RMB could undermine the speculators and eliminate the driving incentives. Fourth, a more market-based exchange rate with reduced intervention, will facilitate further adjustment in reserves. Lastly, despite the fact that RMB internationalization is still at its early stages, flexibility in the exchange rate is one of the factors that influences the RMB's growth prospect as a reserve currency. Reserve currencies trade freely and their external value is market determined. 
As a caveat, it is important that there is no sure, simple and safe route to manage the exchange rate policy in China due to uncertainty. Appropriate regime will differ over time. The shortterm transition costs for widening the band include higher volatility, capital outflows and weakening of RMB. Currency instability will bring uncertainty to China economy. Allowing the market forces to determine the exchange rate of RMB may make long term planning difficult. In addition, the exchange markets may be more prone to exhibiting a herd mentality once the peg is broken. The transition from regulated to liberalized system is a vulnerable period.

The chosen regime has pros and cons and require support from other policies, such as strong banking system and a commitment to sound economic policy. Measures can be taken to enhance the exchange rate regime and reduce the destabilising impact by means of tax on shortterm capital flows, limit on lending by domestic banks to foreigners for currency short-selling, implementation of best-practice in credit and investment standards, and development of financial infrastructure. In general, the strategy should focus on maintaining valuable longterm foreign capital while deterring short-term speculative inflows or hot money. It is important to gradually liberalize capital inflows and outflows but carefully control hot money flows.

[1] For example, in March 2005, the New York's Senator Charles Schumer co-sponsored a bill to impose a $27.5 \%$ tariff on all US imports from China until RMB was appreciated. In February 2010, President Obama stated that China's undervalued currency put US firm at a huge competitive disadvantage.

[2] This finding occurs with Zhang and Sato (2012), who reported that the dynamic effect of exchange rate on China's trade balance was still limited. China's trade balance was found to be affected largely by the world demand shock and trade balance shock.

[3] Following the method of Martin and Morrison (2008), hot money is estimated by subtracting a nation's trade surplus (or deficit) and its net flow of foreign direct investment (FDI) from the change in the foreign reserves.

[4] One common way of approximating the flow of hot money is to subtract a nation's trade surplus or deficit and its net flow of foreign direct investment (FDI) from the change in the nation's foreign reserves (Martin \& Morrison, 2008)

[5] Bloomberg News, January 25, 2016.

[6] As stated by John Greenword, Chief Economist at Invesco Asia. 


\section{References}

Chao, W.-C. and Tung, C.-Y. (2013), "Does China really say no? The impact of international political pressure on China's exchange rate policy", Issues \& Studies, Vol. 49 No. 2, pp. 1-34.

Cheung, Y., Chinn, M. and Fujii, E. (2007), "The overvaluation of renminbi undervaluation”, Journal of International Money and Finance, Vol. 26 No. 5, pp. 762-785.

China Economic Review (2016), "RMB falls to sixth place in global payments", 22 July.

Cline, W.R. (2016), Estimates of Fundamental Equilibrium Exchange Rates, May 2016, Peterson Institute of International Economics, Washington.

Corden, W. (2009), “China's exchange rate policy, its current account surplus, and the global imbalances", The Economic Journal, Vol. 119, pp. 430-441.

Cui, Y. (2014), "Revisiting China's exchange rate regime and RMB basket: A recent emprical study", International Journal of Economics and Finance, Vol. 6 No. 2, pp. 150-160.

Frankel, J. (2004), “On the renmimbi: The Choice between adjustment under a fixed exchange rate and adjustment under a flexible rate", paper written for Seminar on Foreign Exchange System held in Dalian, China, pp. 1-26.

Frankel, J.A. (1999), "No single currency regime is right for all countries or at all times", NBER Working Paper Series, pp. 1-49.

Frankel, J.A. and Wei, S.-J. (2007), "Assessing China's exchange rate regime”, Working Paper for the 44th Panel Meeting of Economic Policy, pp. 1-77.

Goldstein, M. and Lardy, N. (2009), The Future of China's Exchange Rate Policy. The Peterson Insitute for International Economics, Washington DC.

Huang, Y. and Lynch, C. (2013), "Does internationalizing the RMB make sense for China?”, Cato Journal, Vol. 33 No. 3, pp. 571-585. 
International Monetary Fund (2015), “People's Republic of China, staff report for the 2015 Article IV consultation", International Monetary Fund.

International Monetary Fund (2015), "IMF Executive Board completes the 2015 Review of SDR Valuation", Press Release No. 15/543.

Kawai, M. and Liu, L.-G. (2015), "Trilemma challenges for the People's Republic of China”, ADBI Working Paper Series, pp. 1-41.

Lo, C. (2015), “Avoid joining the currency war!”, International Economy, Spring, pp. 66-67, 96.

Martin, M.F. and Morrison, W.M. (2008), “China's 'hot money' problems", CRS Report for Congress, pp. 1-6.

McKinnon, R. (2005), “China's new exchange rate policy: Will China follow Japan into a liquidity trap?", Stanford Institute For Economic Policy Research Discussion Paper Series, pp. 1-13.

McKinnon, R. (2014), “Currency conundrum”, International Economy, Spring, pp. 42-45.

Moosa, I. and Burns, K. (2012), "Do the Chinese exchange rate and trade policies violate international rules?", Transnational Corporations Review, Vol. 4 No. 2, pp. 50-60.

Moosa, I. and Ma, M. (2013), "The US trade deficit as an American problem", Transnational Corporations Review, Vol. 5 No. 1, pp. 12-27.

Prasad, E.S. (2014), The Dollar Trap: How the US Dollar Tightened Its Grip on Global Finance, Princeton University Press, Princeton, NJ.

Prasad, E.S. (2016), "China's efforts to expand the international use of the renminbi", Report prepared for the US-China Economic and Security Review Commission, pp. 1-141.

Rapoza, K. (2016), “Canada's dollar beats China's currency in world trade, but not for long”, Forbes, 21 July. 
Roubini, N. (2007), "Why China should abandon its dollar peg", International Finance, Vol. 10 No. 1, pp. 71-89.

Stiglitz, J. (2005), Stiglitz on China and Why US Economic Advice is Discounted. Economist View.

The Economist (2014), "One way no more: China's currency”, Vol. 410 No. 8876, p. 75.

The Economist, (2016a), "Bending, not breaking; China's currency", Vol. 419 No. 8992, p. 71.

The Economist, (2016b), "Fight or flight; free exchange", Vol. 418 No. 8972, p.84.

Wei, L. (2015), “China's central bank signals intention to loosen yuan's peg to dollar”, Wall Street Journal, available at: http://www.wsj.com/articles/chinas-central-bank-signals-intention-to-loosenyuans-peg-to-dollar-1449843879 (accessed 31 October 2016).

Wei, L. (2016), “China loses resolve to revamp yuan - minutes show renewed tight control over current; Xi's second thoughts", Wall Street Journal, Eastern Edition, 24 May, p. A.1.

Yu, M. (2012), "Does appreciation of the renminbi decrease imports to the United States from China?", Centemporary Economic Policy, Vol. 30 No. 4, pp. 533-547.

Yu, Y. (2016), "China still has room to move on RMB", East Asia Forum, 7 February.

Zhang, Z. and Sato, K. (2012), "Should Chinese renminbi be blamed for its trade surplus? A structural VAR approach", The World Economy, Vol. 35 No. 5, pp. 632-650. 